\title{
Growth Dynamic and Physiological Status of Calves for Meat Production
}

\author{
Vioara MIREŞAN ${ }^{1}$, Petru ŢĂRAN ${ }^{1}$, Camelia RADUCU ${ }^{1}$, Aurelia COROIAN ${ }^{1}$, Daniel COCAN $^{1 *}$ \\ ${ }^{1}$ Faculty of Animal Science and Biotechnologies, University of Agricultural Sciences and Veterinary \\ Medicine Cluj-Napoca, 3-5 Mănăștur Street, 400372, Cluj-Napoca, Romania \\ * corresponding author: daniel.cocan@usamvcluj.ro; cocandaniel@yahoo.com
}

Bulletin UASVM Animal Science and Biotechnologies 73(2)/ 2016

Print ISSN 1843-5262; Electronic ISSN 1843-536X

DOI:10.15835/buasvmcn-asb: 12222

\begin{abstract}
Cattles' farming for meat is an activity specific for Romanian animal breeding sector. Generally, beef cattle farmers acquire calves from the local population. The condition and welfare of calves can be determined based on weight gain and haematological indices. The purpose of our research was to determine the growth dynamic of calves subjected to fattening and to determine the physiological status on growth stages, by haematological investigations. Our research was conducted at the SC ITL AGROCOMPLEX farm - Lechința, Bistrița-Năsăud County. Growth indices (TG - total gain; ADG - average daily gain) were determined based on successive measurements and weighing. The physiological status was determined by haematological analyses (WBC, RBC, HGB, HCT, MCV, MCH, MCHC, leukocyte formula). The experiment lasted for 33 days, 10 calves being studied. The initial mean weight was $53.5 \pm 0.513 \mathrm{~kg}$, and the final mean weight was $91.7 \pm 0.445 \mathrm{~kg}$, resulting a total gain (TG) of $38.2 \mathrm{~kg}$ and an average daily gain (ADG) of $1.158 \mathrm{~kg} /$ day. Generally, the obtained haematological values showed a gradual improvement of the physiological status of calves. Starting with somewhat higher leukocyte values $\left(\mathrm{WBC}_{\text {initial }}=10.61 \pm 0.329 \times 10^{9} / \mathrm{L}\right)$, their level slowly decreased towards the end of the experiment $\left(\mathrm{WBC}_{\text {final }}=8.92 \pm 0.204\right.$ x $10^{9} / \mathrm{L}$ ). Regarding other haematological indices, these presented relatively constant values: $\mathrm{RBC}_{\text {initial }}=9.44 \pm 0.151 \mathrm{x}$ $10^{12} / \mathrm{L}$ vs. $\mathrm{RBC}_{\text {final }}=9.35 \pm 0.114 \times 10^{12} / \mathrm{L} ; \mathrm{HGB}_{\text {initial }}=9.92 \pm 0.234 \mathrm{~g} / \mathrm{dl}$ vs. $\mathrm{HGB}_{\text {final }}=9.24 \pm 0.155 \mathrm{~g} / \mathrm{dl} ; \mathrm{HCT}_{\text {initial }}=30.5 \pm 0.604 \%$ vs. $\mathrm{HCT}_{\text {final }}=30.15 \pm 0.389 \%$. The obtained results show optimum values for growth dynamic. Also, the haematological indices indicate good maintenance, growth and feeding conditions existent in the farm, the indices improving during the experiment.
\end{abstract}

Keywords: calves, meat production, growth dynamic, haematology

\section{INTRODUCTION}

Bovine farming for meat represents a good alternative for farmers, considering an overproduction of milk and its decreasing market price. Haematological investigations reveal the physiological status of farm animals (Jackson and Cockcroft, 2002). Depending on the conducted analyses, measures can be taken regarding the feed structure and the quantity of feed that needs to be administrated to the animals, and also the environmental conditions that need to be ensured (Van Saun, 2000). All these lead to a growth dynamic suitable to the proposed objective, in our case this being breeding calves for meat production. The finality of haematological investigations can be found in the economic efficiency of farms.

\section{AIMS AND OBJECTIVES}

Our research had the objective of determining the growth dynamic of calves subjected to fattening and determining the physiological status on growth stages, by haematological investigations.

\section{MATERIALS AND METHODS}

Our study was conducted in a fattening calves farm from Bistrița-Năsăud County. 10 calves were studied, in terms of the weight gain, within a period of 33 days. Also, haematological indices were determined at the start of the study, after two weeks and at the end of the study. Blood samples were collected from the jugular veins. Calves were acquired from local farmers and weaned and 
Tab. 1 Daily forage intake administered to the calves in the first stage of fattening

\begin{tabular}{|c|c|c|c|c|c|c|c|c|}
\hline \multirow{2}{*}{ Forage } & \multicolumn{2}{|c|}{ Feed ratio } & \multirow{2}{*}{$\mathrm{kg} /$ day } & \multirow{2}{*}{$\begin{array}{r}\text { DM } \\
(\mathrm{kg})\end{array}$} & \multirow{2}{*}{$\begin{array}{c}\text { Nutrition } \\
\text { units }\end{array}$} & \multirow{2}{*}{$\begin{array}{c}\text { DCP } \\
\mathrm{g}\end{array}$} & \multirow{2}{*}{$\begin{array}{c}\mathrm{Ca} \\
\mathrm{g}\end{array}$} & \multirow{2}{*}{$\begin{array}{l}\mathrm{P} \\
\mathrm{g}\end{array}$} \\
\hline & $\%$ & $\mathrm{~kg}$ & & & & & & \\
\hline Mixed fodder I* & 50.00 & 0.50 & 1.00 & 0.805 & 1.028 & 182.98 & 0.918 & 4.622 \\
\hline Hay & 25.00 & 0.25 & 0.50 & 0.430 & 0.245 & 42.00 & 3.200 & 0.950 \\
\hline Forage milk powder & 25.00 & 0.25 & 0.50 & - & - & - & - & - \\
\hline Total ration & 100.00 & 1.00 & 2.00 & 1.235 & 1.273 & 224.98 & 4.118 & 5.572 \\
\hline
\end{tabular}

Tab. 2 Daily forage intake administered to the calves in the second stage of fattening

\begin{tabular}{|c|c|c|c|c|c|c|c|c|}
\hline \multirow{2}{*}{ Forage } & \multicolumn{2}{|c|}{ Feed ratio } & \multirow{2}{*}{$\mathrm{kg} /$ day } & \multirow{2}{*}{$\begin{array}{l}\mathrm{DM} \\
(\mathrm{kg})\end{array}$} & \multirow{2}{*}{$\begin{array}{c}\text { Nutrition } \\
\text { units }\end{array}$} & \multirow{2}{*}{$\begin{array}{c}\text { DCP } \\
\mathrm{g} \\
\end{array}$} & \multirow{2}{*}{$\begin{array}{c}\mathrm{Ca} \\
\mathrm{g} \\
\end{array}$} & \multirow{2}{*}{$\begin{array}{l}\mathrm{P} \\
\mathrm{g} \\
\end{array}$} \\
\hline & $\%$ & $\mathrm{~kg}$ & & & & & & \\
\hline Mixed fodder II* & 71.43 & 0.714 & 5.00 & 4.007 & 4.988 & 741.80 & 6.138 & 29.85 \\
\hline Hay & 28.57 & 0.286 & 2.00 & 1.720 & 0.980 & 168.00 & 12.80 & 3.80 \\
\hline $\begin{array}{c}\text { Total ration } \\
\text { te: */maize barley }\end{array}$ & $\frac{100.00}{\text { ean grist. }}$ & $\begin{array}{l}1.00 \\
\text { at bran }\end{array}$ & $\frac{7.00}{1 \mathrm{x}) \mathrm{DM}-\mathrm{d}}$ & $\frac{5.727}{\text { er:DCP-di }}$ & $\frac{5.968}{\text { e crude } \mathrm{pr}}$ & 909.80 & 18.938 & 33.65 \\
\hline
\end{tabular}

Tab. 3 Calves growth indices (TG and ADG) in the 33 experimental days

\begin{tabular}{|c|c|c|c|c|}
\hline Measurement sessions & MU & $\mathrm{X} \pm \mathrm{sx}$ & Total gain TG $(\mathrm{kg})$ & Average daily gain ADG (kg/day) \\
\hline $1(23.02 .2016)$ & $\mathrm{kg}$ & $53.50 \pm 0.513$ & \multirow{3}{*}{38.20} & \multirow{3}{*}{1.158} \\
\hline $2(11.03 .2016)$ & $\mathrm{kg}$ & $72.60 \pm 0.508$ & & \\
\hline $3(25.03 .2016)$ & $\mathrm{kg}$ & $91.70 \pm 0.445$ & & \\
\hline
\end{tabular}

Tab. 4 Values and variability of the haematological parameters

\begin{tabular}{cccccccc}
\hline \multirow{2}{*}{ Specification } & \multirow{2}{*}{ MU } & \multicolumn{2}{c}{ Session 1 $(\mathrm{n}=10)$} & \multicolumn{2}{c}{ Session 2 $(\mathrm{n}=9)$} & \multicolumn{2}{c}{ Session 3 (n=10) } \\
\cline { 3 - 7 } & & $\mathrm{X} \pm \mathrm{sx}$ & $\mathrm{V} \%$ & $\mathrm{X} \pm \mathrm{sx}$ & $\mathrm{V} \%$ & $\mathrm{X} \pm \mathrm{sx}$ & $\mathrm{V} \%$ \\
\hline WBC & $\mathrm{x} 10^{9} / \mathrm{L}$ & $10.61 \pm 0.329$ & 31.04 & $8.88 \pm 0.151$ & 17.05 & $8.92 \pm 0.204$ & 22.86 \\
\hline LYM & $\mathrm{x} 10^{9} / \mathrm{L}$ & $6.4 \pm 0.245$ & 38.36 & $5.9 \pm 0.165$ & 27.90 & $6.06 \pm 0.214$ & 35.37 \\
\hline MON & $\times 10^{9} / \mathrm{L}$ & $0.22 \pm 0.029$ & 129.99 & $0.1 \pm 0.004$ & 37.65 & $0.16 \pm 0.023$ & 146.68 \\
\hline NEU & $\times 10^{9} / \mathrm{L}$ & $3.76 \pm 0.189$ & 50.24 & $2.59 \pm 0.133$ & 51.53 & $2.54 \pm 0.1$ & 39.55 \\
\hline EOS & $\times 10^{9} / \mathrm{L}$ & $0.16 \pm 0.009$ & 56.13 & $0.27 \pm 0.015$ & 54.93 & $0.16 \pm 0.007$ & 44.78 \\
\hline BAS & $\times 10^{9} / \mathrm{L}$ & $0.01 \pm 0.001$ & 105.41 & $0.01 \pm 0.001$ & 75.00 & $0.01 \pm 0$ & 52.70 \\
\hline RBC & $\mathrm{x} 10^{12} / \mathrm{L}$ & $9.44 \pm 0.151$ & 16.02 & $9.17 \pm 0.104$ & 11.30 & $9.35 \pm 0.114$ & 12.14 \\
\hline HGB & $\mathrm{g} / \mathrm{dl}$ & $9.92 \pm 0.234$ & 23.59 & $8.96 \pm 0.17$ & 18.96 & $9.24 \pm 0.155$ & 16.74 \\
\hline HCT & $\%$ & $30.5 \pm 0.604$ & 19.81 & $28.95 \pm 0.452$ & 15.61 & $30.15 \pm 0.389$ & 12.90 \\
\hline MCV & $\mathrm{fl}$ & $32.3 \pm 0.263$ & 8.13 & $29.16 \pm 0.69$ & 23.66 & $32.3 \pm 0.17$ & 5.27 \\
\hline MCH & $\mathrm{pg}$ & $10.42 \pm 0.115$ & 11.04 & $12.22 \pm 0.827$ & 67.67 & $9.84 \pm 0.065$ & 6.57 \\
\hline MCHT & $\mathrm{g} / \mathrm{dl}$ & $32.32 \pm 0.155$ & 4.79 & $29.88 \pm 0.178$ & 5.95 & $30.5 \pm 0.136$ & 4.45 \\
\hline
\end{tabular}

later fed according to the daily forage intake, as presented in tab. 1 and tab. 2 .

Growth indices were determined (TG - total gain; ADG - average daily gain) based on successive measurements and weighting. The physiological status was determined by haematological analyses (WBC, RBC, HGB, HCT, MCV, MCH, MCHC, leukocyte formula).

\section{RESULTS AND DISCUSSION}

The growth indices of the calves from the 33 days of experiment are presented in table 3 . The mean total gain obtained was $38.20 \mathrm{~kg}$, while the average daily gain was $1.158 \mathrm{~kg} /$ day. The mean values and the variability of the haematological parameters of the studied calves are presented in table 4. A gradual decrease in the leukocyte 
number can be observed, similarly to the other study (Benesi et al., 2012).

\section{CONCLUSION}

Based on the gathered data it is notes a good calf growth dynamic and a gradual, but significant improvement of the physiological status. This demonstrates good growth condition and a good quality of the administered feed.

\section{REFERENCES}

1. Jackson PGG, Cockcroft PD (2002). Clinical examination of farm animals. Blackwell Science Publishing Company.

2. Van Saun RJ (2000). Blood profiles as an indicator of nutritional status. Advances in Dairy Technology, 12: 401410.

3. Benesi FJ, Teixeira CMC, Leal MLR, Lisboa JAN, Mirandola RMS, Shecaira CL, Gomes V (2012). Leukograms of healthy Holstein calves within the first month of life. Pesquisa Veterinaria Brasileira, 32(4): 352-356. 